\title{
Development of Civics Caring Apps as an Effort to Character Students in the Covid-19 Pandemic Period
}

\author{
Mutiara Imtisyal Ammatulloh ${ }^{1 *}$, Noviani Permana ${ }^{2}$, Rizwan Firmansyah ${ }^{3}$, \\ Lussy Nur Sha'adah ${ }^{4}$, Zahra Ihsani Izzatunnisa ${ }^{5}$, Dwi Iman Muthaqin ${ }^{6}$ \\ 1,2,3,4,5,6 Universitas Pendidikan Indonesia, Bandung, Indonesia \\ Corresponding Author: mutiaraimtisyal@upi.edu
}

\begin{abstract}
This research presents an approach in cultivating and shaping the character of students at the elementary school level through Prototype Civics Caring (Character Building) Apps as an Android-based learning media that integrates learning models Value Clarification Technique (VCT) with games-based learning methods. Currently there are many applications that aim to instill character education in children, but not many applications provide an introduction to character building from the perspective of children and parents, testing understanding, and monitoring student activities, as well as testimonials that parents or guardians can fill out in every month. During the Covid-19 pandemic, learning activities were carried out online, which of course decreased the effectiveness of teachers in controlling the character building of students. Therefore, the Civics Caring Apps Prototype presents a character values planting scheme that aims as a special medium that can monitor and control the character formation of students. The method used is the design and development (D\&D) model research method or design and development. The data collection method is done by studying literature, interview, and questionnaire. The contribution of research to science includes the field of Citizenship Education and the field of Sociology. The results of this study are user tasks, evidence of student character changes, prototype design and android applications in providing understanding of character values with good user experience and interactive content display to motivate students to implement each positive character value they learn.
\end{abstract}

Keywords: Character building, Online learning, Prototype Civics Caring (Character Building) Apps, Student monitoring.

\section{INTRODUCTION}

Basically, the purpose of education is not just to produce citizens who are academically intelligent, but another purpose of an education is to produce citizens who have noble character and character in harmony with the constitution. This is enshrined in Law Number 20 of 2003 concerning the National Education System. In 2018, KPAI handled 1,885 cases in the first semester. From this figure, children in conflict with the law $(\mathrm{ABH})$ who become perpetrators of narcotics crimes, theft, and immoral acts are the most cases. This reality is certainly the reason for how important it is to instil character education in children from an early age.

In addition to parents, teachers and educational institutions are one of the parties who also control the formation of children's character. Thus, teachers and schools must synergize with each other to create a learning climate that inculcates character values. In line with this, [1] the position of character in the learning process is so crucial that the teacher must really be able to touch the roots to the roots of this character. However, teacher supervision is limited only when teaching and learning activities take place in the classroom. This was then exacerbated by the emergence of the Coronavirus Disease (Covid-19) pandemic which in the last few months hit almost all regions in the world, including Indonesia. The emergence of the pandemic ultimately affected the order of the education process in Indonesia, namely online learning.

In implementation, bold learning has an effect on the effectiveness of teachers in controlling the character formation of students [2]. A decline in character for students during the pandemic, because character education during the Covid-19 pandemic must pay attention to the basic character development itself, namely cognitive development, social development, and students' moral development. Due to the limitations of space and time in bold learning, it 
seems to be a barrier for teachers in instilling character values in students [3].

Based on this reality, a special media is needed that can monitor and control the formation of the character of students. The media must be in line with technological advances and the interests of students today. So, the research team intends to conduct research on these problems through an application that integrates character education-based learning media with technology. Therefore, through the implementation of digital literacy Prototype Civics Caring (Character Building) Apps, it is hoped that it will further increase the effectiveness and efficiency in monitoring the character formation of students in the digital era.

Beside to the things mentioned above, this research has the aim of increasing the knowledge and insight of researchers and the community regarding the impact of learning on the process of forming student character, things that are supporting factors and inhibiting the process of forming student character during the Covid-19 pandemic., the steps taken by the teacher as an effort to build character during the Covid-19 pandemic, as well as providing understanding to students, parents and teachers regarding the design for the operation of the Civics Caring (Character Building) application.

The benefits expected from this research are to provide an overview of scientific studies, especially social science and civic education regarding the factors and impacts of the character formation process during the Covid-19 period and the use of digital media in reducing the effectiveness of learning student character formation. In addition, with this research, it is hoped that it can provide insight and understanding to students about the importance of character building from an early age and provide space and access to teachers in conducting supervision and monitoring as an effort to build student character without being limited by space and time.

\section{THEORETICAL REVIEW}

\subsection{The Concept of Learning and Network}

Learning in the network is learning done digitally through an application platform that can help and support the process of learning teaching. Competence that an educator will teach through learning in this network must be noted, and is based also on pedagogical, psychological, and ecclesiastical aspects [4].

Based on that reality, a special medium is needed to monitor and control the formation of learners' character. Such media should be in harmony with technological progress and the current interest of learners. Therefore, the research team intends to do research on the problem through an application that integrates technology-based social-education media. Therefore, through the implementation of the digital literacy of the Civics Caring (Character Building) Apps, it is hoped to enhance the effectiveness and efficiency of monitoring of the developing character of students in the digital age.

In addition to the foregoing, this study has the purpose of increasing the knowledge and insight of researchers and communities in its people regarding the effects of online learning on the student's character creation process, things that are both supporting and inhibitory to the student's character creation process during the Covid-19 pandemic, the measures teachers take as student development attempts at the Covid-19 pandemic, And provide understanding to students, parents and teachers related the civics caring application design.

However, learning in the network must continue through the process of planning, implementation, and evaluation just as much as learning outside the network [4]. What is different about offline learning is that online learning is superior in terms of time, cost, and unlimited access.

Online learning has a central characteristic, which is as follows; Is performed first on the network, online learning is done through application platforms or web networking. Generally, educators give materials with video footage, slideshow, text, charts and various other multimedia elements, communications that can be conferencing or chats rooms, and then there are tasks to be done along with a predetermined work schedule. The second characteristic is massif, this online learning can reach an unlimited number of participants through the Internet. And finally open, this online learning system is open to access to all of those good people, the education people, and the general public [5].

\subsection{Character Components}

Character in the meaning is not to devoid of a attitudes series, motivations, behaviors, motivations as well as skill. Character may be defined as a disposition that has been inherent in everyone. This character results from the internalization of the individual around the environment that makes the individual a basis for behavior resulting in a distinctive characteristic of the individual [6]. Character has several components to form into a good character. These include moral soundness, moral sense and action morals [6].

Moral inclusion is one of the components that must be taught in the character education process. The Shared moral awareness, the perpetuity of values, perspective taking, the moral ignorance, the incremental decision and also self-knowledge. And the second component is moral sense. A moral sense is an aspect that must be instilled in humans because it is judged that human are a source of energy to act in harmony with existing moral principles. Moral feeling is morality, morality, empathy, loving the good, morality as well as morality. The final component is 
moral action. Knowledge and emotions are imperfect without action. Moral action means one of the manifestations of moral clarity and moral feeling. In its embodiment, it must be considered another aspect of form a good character, which is competence, desire, and habits.

\subsection{Process of character Building}

Forming the real character is not a short process. It is known that the success of an individual in society is back against the background by $80 \%$ of the level of emotional intelligence that results from good character education [7].

The process of character development is not independent of character education which is of vital importance in establishing an identity. However, what needs to be highlighted is the process of characterbuilding through character education must involve all parties. Such as family, school, and community. The first step in shaping a character is first developing between the three supporting things. Because, character development and education will not succeed as long as these three things are not sustained [8].

\section{METHODS}

The research method used is design and development, as defined by Richey and Klein, a model usually used to study a design process, development and evaluation with a view to forming an empirical basis for both learning and non-learning activities and creating or enhancing the model that regulates its development [9]. The focus in demographic research includes analysis, planning, production, and or evaluation. Design and development in developments as research models focus not only on product outcomes, but on the findings of the products that have been developed.

In the research procedure taking opinions from prefers, etc [10]. which identifies the six large steps depicted on the chart below:

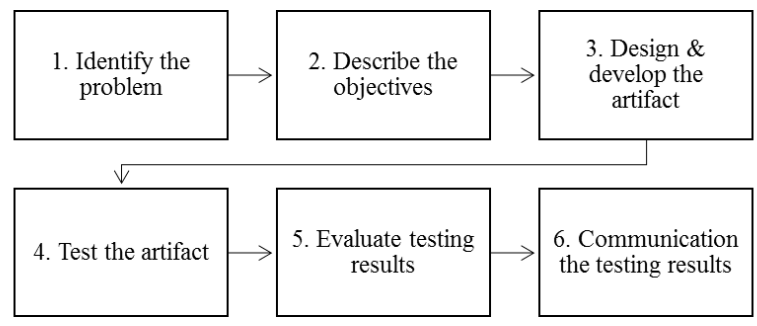

Figure 1. Research Procedure

The research procedure begins with identifying the problem of identifying the teacher's limitations in creating the primary school character of learners through online learning at the time of the covid-19 pandemic. Then describe the goals (objectives the objectives), based on problems already concluded at the point, it has been found that the purpose of this study in general is to design and develop a learning medium that can enable teachers to monitor educational activities and can instill values and morals that will stimulus in developing the student's character at an elementary school level. Third, the design and development of the product (design $\&$ artifact), was the number-one step in this research activity. The device or product referred to in the study is the civics caring apps prototype. Fourth conducted test results and test results (the artifact and the testing results). The fifth communicated the results of the test (testing the test results) and the results of both previous assessments or data analysis on the process were then established for analysis.

Participants in this assessment involve students and teachers at the elementary school level. The approach used is a combination of qualitative and quantitative. Qualitative data to know the conditions in the field presented by the teacher. Quantitative data obtained from an questionnaire is subsequently distributed to qualitative data on a scale of 4 (likert scale) to identify the quality of the product. Assessments or data analyses of the previous process are led to conclusions, such as how his contribution to the development of science in education, and what a future step could be taken to follow up on the results of the trials to expand this research topic. The datacollecting method in this study includes literacy, interviews, and questionnaire. The technique is used to explore information based on the learner's point of view regarding the effectiveness of character education given by the teacher through online learning.

\section{RESULT AND DISCUSSION}

\subsection{The Impact on the online learning during COVID-19 pandemic}

Learning in the issues that have been performed since the advent of the covid-19 pandemic has affected the school learning process. The effects are felt not only as to the diminishing effectiveness of teachers giving teaching materials to students but also as to the slowing down of the student character creation process. Ideally, in the process of shaping a teacher's character must engage and observe firsthand the affective aspects of a learner. According to noer et al., (2017), how much better a character education is implemented through behaviour in the school environment both its conditions and its activities [11].

In reality, since the advent of the covid-19 pandemic, the process of student formation at school has been challenged. During learning in a teacher's network the teacher cannot judge a student's character directly [12]. Beyond the very limited control and supervision of teachers, it is then exacerbated by limited teacher and disciple communication. Based on the Numbers that have been dispersed with the sample are the elementary school students in Bandung. The majority of respondents assume that learning in the tissues carried out during the covid-19 pandemic has affected the decline in the effectiveness of student character-building processes in schools. This is 
because students are unable to see and feel first-hand the teacher figure they are accustomed to being an example or an example to the students.

In the implementation of online learning, many teachers complain about the participation of learners especially at the level of elementary schools. Based on an interview with miss Ernawatie asa private teacher teaching in the area of Bandung can be concluded that when the study begins at home, children have so much to do with a teacher at her school, where the teacher gives her an assignment every week and it builds up, and the parenting role is so desperately needed in the classroom. But there are parents who complain about such circumstances that they are so overwhelmed with their children at their side of the study, since they are also required to work for their daily lives that children are neglected at home and children are lazy about their online tasks and cause teachers to become concerned about their character.

As a result of the interview with miss elis as an elementary school teacher in the area of Bandung district said at this point during this pandemic many learners who have changed their character and behaviour, especially to their own teachers, there are learners who ignore the online tasks given by teachers, and there are those who do not read the messages of duty directive given by the teacher, Worse yet there were trainees who deliberately left the group.

Even the impact of online learning can be felt in the process of learning assessments, if a direct study in a school is usually a test or a test, teachers can have direct supervision, so that learners can be directed to honest work on the problem, now the circumstances change, no one can watch and see whether the issues are done independently and prayerfully. This means it will be difficult for teachers to determine whether they are honest or not.

If viewed from another standpoint, learning in the tissues can also turn out to support the process of creating a student character. This can be seen from the learning mechanisms carried out during the covid-19 pandemic by some schools in Bandung. There are several schools that investigate learning in the tissues by creating study groups around students' neighborhoods. The learning method used was the method of cooperative learning. The study of the method of cooperative learning benefits the development of student character [13]. This is because children and parents have more interaction times than when children are studying in school.

\subsection{Prototype Civics Caring (Character Building) Apps}

On the design of this application will integrate the technology-based based learning media. The idea that the lifts researcher is renewables on this study is to adopt the civics caring (character building) apps prototype as a digitally based character education medium that integrates between the learning model
Value Clarification Technique (VCT) and the method of games-based learning. With the application it is a solution that we offer to improve the effectiveness and efficiency of locating character development to learners in online learning by adjusting to technological progress and the interest of learners.

The presence of this application can be the solution in the development and improved positive character of learners, through understanding the wise use of information technology. So, in use it will increase both effectiveness and efficiency as media in the process of developing the character of learners. This application scheme has features to compile the character of participants, the menu found in:

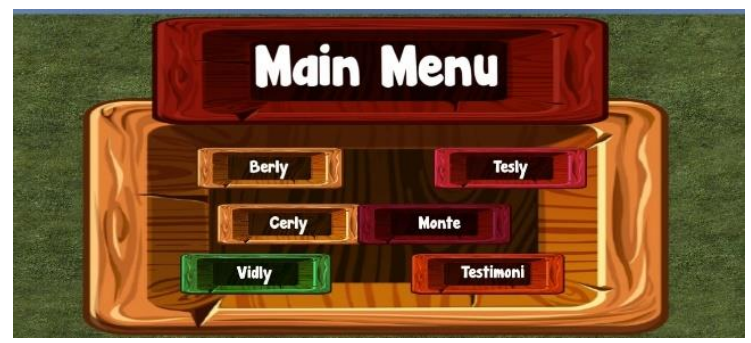

Figure 2. Civic Caring Apps Menu

1. Berly (studying with Carly), contains interactive materials related character values that should be had by learners.

2. Cerly (Carly's story), contains a collection of texts or folklore containing messages and morals that learners can imitate.

3. Vidly (videos from Carly), contains a video showing of the diversity of nations and tolerance values.

4. Tesly, which consists of an educational game in the form of a collection of problems inside of a level of level where each level has a score or a value as a reward, to encourage learners to be more motivated.

5. Monte (monitoring for friends) says of the activities the trainees have done.

6. The testimony of father and mother, containing the responses of parents or guardians of learners, related civics caring apps.

Based on a test obtained from an questionnaire file that had been distributed with samples, it was an elementary school student in Bandung. The test of the civics caring apps was based on 12 aspects of them:

Tabel 1. Civics Caring Apps Test Result

\begin{tabular}{|l|l|c|c|c|}
\hline No & \multicolumn{1}{|c|}{$\begin{array}{c}\text { Valued } \\
\text { Aspect }\end{array}$} & Score & Average & Category \\
\hline 1. & $\begin{array}{l}\text { Clarity for } \\
\text { Learning }\end{array}$ & 84 & 3,36 & Very good \\
\hline 2. & $\begin{array}{l}\text { Clarity of } \\
\text { material } \\
\text { description }\end{array}$ & 87 & 3,48 & Very good \\
\hline 3. & $\begin{array}{l}\text { Opportunities } \\
\text { for student to }\end{array}$ & 86 & 3,44 & Very good \\
\hline
\end{tabular}




\begin{tabular}{|l|l|c|c|c|}
\hline & $\begin{array}{l}\text { practice on } \\
\text { their own }\end{array}$ & & & \\
\hline 4. & $\begin{array}{l}\text { Clarity of the } \\
\text { language }\end{array}$ & 84 & 3,36 & Very good \\
\hline 5. & $\begin{array}{l}\text { Match the } \\
\text { pictures to } \\
\text { clarify content }\end{array}$ & 80 & 3,2 & Good \\
\hline 6. & $\begin{array}{l}\text { Match the } \\
\text { video to clarify } \\
\text { content }\end{array}$ & 78 & 3,12 & Good \\
\hline 7. & $\begin{array}{l}\text { Animation } \\
\text { Compatibility } \\
\text { to clarify } \\
\text { content }\end{array}$ & 78 & 3,12 & Good \\
\hline 8. & $\begin{array}{l}\text { Freedom to } \\
\text { choose menu }\end{array}$ & 82 & 3,28 & Very good \\
\hline 9. & $\begin{array}{l}\text { Powe of } \\
\text { music Support }\end{array}$ & 78 & 3,12 & good \\
\hline 10. & $\begin{array}{l}\text { Ketetapan } \\
\text { pemilihan } \\
\text { warna } \\
\text { background } \\
\text { dan warna } \\
\text { tulisan }\end{array}$ & 90 & 3,6 & Very good \\
\hline 11. & $\begin{array}{l}\text { Selection of } \\
\text { background } \\
\text { color and the } \\
\text { writing color }\end{array}$ & 86 & 3,44 & Very good \\
\hline 12. & $\begin{array}{l}\text { The display of } \\
\text { animated view } \\
\text { presented }\end{array}$ & 90 & 3,6 & Very good \\
\hline & Total & $\mathbf{1 0 0 3}$ & $\mathbf{4 0 , 1 2}$ & Very \\
Average & $\mathbf{3 0 0 d}$ \\
\hline & & & & \\
\hline
\end{tabular}

The number of assessments based on the field test data involving 25 learners with 12 indicators is 1003 so that the average result based on the test results is 3,34 . So it can be concluded that the Civics Caring Apps according to the student response is very good. While the results of the above evaluation may provide an idea of what to improve on the Prototype Civics Caring Apps, knowing of some of the flaws is hoped to bring new ideas and ideas to the development of innovation based on apps.

\section{CONCLUSION}

Based on research already done by researchers, it may be concluded that the presence of Civics Caring Apps can enhance students insight and teacher's effectiveness in monitoring and controlling students character at the time of the Covid-19 pandemic.

\section{ACKNOWLEDGMENTS}

Thanks to Allah SWT for his presence which has bestowed his grace in finishing this article. The writer expresses thanks to Dwi Iman Muthaqin, S.H., M.H. as guidance professor, Dr. Susan Fitriasari, M. Pd. As head of the bachelor study program. Thanks, to parents and friends for the support and inspiration and all who have assisted in this study.

\section{REFERENCES}

[1] Defi W. F, "Manajemen Karakter Peserta Didik Pesantren di Era Pandemi," vol. 21, p. 1, 2020.

[2] Supriadi, dkk, "Analisis Problema Pembelajaran Daring Terhadap Pendidikan Karakter Peserta Didik," J. Ilmu Pendidik., vol. 3, no. 1, pp. 165173, 2021.

[3] Nafisah, Zafi, "Model Pendidikan Karakter Berbasis Keluarga Perspektif Islam di Tengah Pendemi Covid-19. Ta'allum," J. Pendidik. Islam, vol. 8, no. 1, pp. 1-20, 2020.

[4] Syarifudin, A. S, "Impelementasi Pembelajaran Daring Untuk Meningkatkan Mutu Pendidikan Sebagai Dampak Diterapkannya Social Distancing," J. Pendidik. Bhs. dan Sastra Indones. Met., vol. 5, no. 1, pp. 31-34, 2020, doi: 10.21107/metalingua.v5i1.7072.

[5] Qomarudin \& Bilfaqih, Esensi Pengembangan Pembelajaran Daring Panduan Berstandar Pengembangan Pembelajaran Daring untuk Pendidikan dan Pelatihan. Yogyakarta: Deepublish, 2015.

[6] Maunah, B., "Implementasi Pendidikan Karakter Dalam Pembentukan Kepribadian Holistik Siswa.," J. Pendidik. Karakter, vol. 5, no. 1, pp. 90-101, 2015.

[7] Fransiska, "Undang-Undang Republik Indonesia Nomor 20 Tahun 2003 Tentang Sistem Pendidikan Nasional," vol. 60, no. 1, pp. 147-173, 2003, [Online]. Available: file://C:/Users/rizwan/AppData/Local/Mendele y Ltd./Mendeley Desktop/Downloaded/Fransiska - 2003 Undang-Undang Republik Indonesia Nomor 20 Tahun 2003 Tentang Sistem Pendidikan Nasional.pdf.

[8] Subianto, J., "Peran Keluarga, Sekolah, Dan Masyarakat Dalam Pembentukan Karakter Berkualitas," Edukasia J. Penelit. Pendidik. Islam, vol. 8, no. 2, pp. 331-354, 2013, doi: 10.21043/edukasia.v8i2.757.

[9] Richey \& Klein, Design and Development Research Methodhs, Strategies, and Issues. New York: Ruotledge., 2007.

[10] Ellis \& Levy, A Guide for Novice Researchers: Designand Development Research Methods. Dalam Proceedings og Informing Science \& IT Education Conference (InSITE). Florida: Nova Southeastern University., 2010.

[11] Noer, A., Tambak, S., \& Sarumpaet, "Konsep Adab Peserta Didik dalam Pembelajaran Menurut AzZarnuji dan Implikasinya terhadap Pendidikan Karakter di Indonesia. Al-Hikmah," J. Agama dan Ilmu Pengetahuan., vol. 14, no. 2, pp. 181-208, 2017, [Online]. Available: https://doi.org/10.25299/alhikmah:jaip.2017.vol14(2).1028. 
[12] Aji Syah Halal Rizqon, "Dampak Covid-19 Pada Pendidikan Indonesia: Sekolah, Keterampilan dan Peroses Pembelajaran," J. Budaya Sos. dan Syar'i, vol. 7, no. 5, pp. 397-398, 2020.

[13] Ariawan, S., "The Effectiveness of Cooperative
Learning Method (Student Team Achievement Divisions) in Christian Education.," IJECA J. Educ. Curric. Appl., vol. 1, no. 3, 2018, [Online]. Available:

https://doi.org/10.31764/ijeca.v1i3.2128. 